\title{
Acid rain - do shallow perceptions hinder progress?
}

London

EUROPEAN pressure on Britain to mend its ways on $\mathrm{SO}_{2}$ emissions and vehicle exhausts could be alleviated by diplomacy, according to a report* issued this week by the British Policy Studies Institute and the Royal Institute of International Affairs. The report says that many of the difficulties over acid rain have arisen because of the shallow understanding by European states of each others' cultural and economic problems.

Much of the interest of the report bears on the long-standing disagreements between Britain and the Scandinavian countries about the degree to which atmospheric pollution from British sources damages recipient areas to the north-east. Britain and its public utilities, such as the Central Electricity Generating Board (CEGB), have been accused of dragging their feet on emission control.

Much of the report consists of an account of the internal factors that have determined the policies adopted in the affected European states, as follows:

Sweden. Affected by environmental damage to thousands of lakes, Sweden is disposed to give high priority to environmental issues. Its own $\mathrm{SO}_{2}$ emissions are planned to fall by 65 per cent between 1980 and 1995. From later this year, all new vehicles will be required to comply with the tight US standards for $\mathrm{NO}_{x}$ emissions. The report says that Sweden, believing that East European countries will not be able to afford to reduce their emissions, is resigned to continuing pollution from them, but that it is far less charitable towards Britain.

West Germany. In the early 1980s, West Germany was stung into action by growing awareness of forest damage, considered an important part of the national heritage. The resulting policies are based on the view that the control of emissions can and should be afforded. But in spite of the installation of sulphur scrubbers and tax incentives for catalytic converters and unleaded motor fuel, significant reductions have not yet been achieved.

France. Because of its investment in nuclear power, France may benefit economically as other countries spend resources on reducing emissions. France is not regarded as a major source of damaging emissions but has undertaken to reduce emissions significantly.

Great Britain. While a significant contributor of sulphur depositions abroad, Britain is now requiring CEGB to install scrubbers on a scale sufficient to ensure continuing reduction of emissions. But the government resists a guarantee of faster progress on the grounds that there is insuf- ficient evidence that Scandinavian catchments would recover so much more quickly that the cost would be justified.

The report notes that Britain is also exposed to political pressure from the European Communities, concerned not only about pollution but that there should be uniform standards affecting competition between European states.

The report suggests that there should be an attempt to make better known elsewhere the "considerable efforts" made in Britain to "safeguard environmental values". Specifically, it says that the Department of the Environment should be strengthened and that there should be fiscal incentives to persuade industry towards energy conservation.

Philip Campbell

- NEw estimates of trans-European sulphur and nitrogen budgets significantly increase the proportions of harmful depositions that can be attributed to source countries, particularly Britain. But

the new figures are unlikely to lead to a change in British policy which is more sensitive to estimations of ecosystem consequences.

The estimates come from the well-respected model of Anton Eliassen and colleagues at the Norwegian Meteorological Institute. Previous models of sulphur transport attributed about 14 per cent of depositions on southern Norway to Britain, but left about 50 per cent unattributed partly due to lengthy and circuitous airmass trajectories. The new model reduces the unattributable proportion considerably, identifying Britain as the source of 43 per cent of depositions with West Germany ranked second at 11 per cent.

The model has also been extended to account for nitrogen transport and deposition. Preliminary indications are that nitrogen oxides are transported at least as far as sulphur oxides and that the deposition differences of the two species mostly reflect differences in the geographical distribution of the respective sources.

* Acid Deposition and Vehicle Emissions: European Environ mental Pressures on Britain, by Peter Brackley. Energy paper 22 of the Joint Energy Programme, by Gower Publishing Company Ltd, Gower House, Croft Road, Aldershot, Hants GU11 pany Ltd,

\section{UK participation in CERN is still hanging in the balance}

\section{London}

AN international review of the European Organization for Nuclear Research (CERN) has failed to identify the level of budget savings that would guarantee Britain's continuing collaboration in the 14-nation venture. The review committee, set up at the request of Britain under the chairmanship of Professor Anatol Abragam to consider the means and possible impact of reductions in the running costs of the laboratory, presented an interim report to the committee of CERN council last week. The 40-page document, which has not been published, criticizes the management of CERN, but emphasizes the excellence of the science.

The main recommendations of the review committee are a reduction in staff of between 10 and 15 per cent (400-600 people), commencing in 1988-89, and changes in the employment status of some permanent staff, to incorporate them into the French or Swiss national employment systems. A substantial reduction in the number of permanent contracts is called for, but no reduction of the science budget is recommended.

The immediate effect of the interim report has been agreement by the CERN council to limit the recruitment of new staff and to offer no new permanent positions, except where formal commitments have already been made.

In the meantime, a CERN management team will be convened by the directorgeneral to study the feasibility and consequences of the preliminary recommendations. The Abragam committee will present its final report at the December meeting of CERN council, but it is unlikely that further significant action will be recommended.

The review committee expects savings approaching the 25 per cent by 1991-92 called for by a panel chaired by Sir John Kendrew, set up in 1985 at the request of the British government. Britain's Advisory Board for the Research Councils (ABRC) earlier this year recommended that the annual UK contribution should be around $£ 30$ million. But last year a sharp fall in the value of the pound against the Swiss franc meant Britain's contribution increased to $£ 55$ million, compared with $£ 37.9$ million in $1985-86$.

ABRC's attitude towards continuing collaboration will depend on the precise level of savings attainable if Abragam's recommendations are all adopted, and on the outcome of the Treasury's public expenditure survey in the autumn. Given that withdrawal from CERN requires notice of a full calendar year, it seems unlikely that Britain will wait for the review committee's final report. ABRC and the Science and Engineering $\mathrm{Re}$ search Council will consider the preliminary recommendations next month.

Simon Hadlington 